\title{
IS 35 U.S.C. § 271(F) KEEPING PACE WITH THE TIMES?: THE LAW AFTER THE FEDERAL CIRCUIT'S CARDIAC PACEMAKERS DECISION
}

\author{
Lauren Shuttleworth
}

\section{INTRODUCTION}

In a common business arrangement, an American software company designs software in the United States, then sends the software code abroad where copies are mass-produced and distributed. Prior to the Federal Circuit's ruling in Cardiac Pacemakers, Inc. v. St. Jude Medical, Inc., the American company could have been found liable for patent infringement under Section 271(f) of the Patent Act if the software mass-produced abroad infringed a United States patent. ${ }^{1}$ Cardiac Pacemakers, however, leaves United States patent owners defenseless when the allegedly infringed patent claims are method claims. The background of Cardiac Pacemakers, the Court's rationales, and the implications of the decision are the subject of this Note.

\section{A. A Global Economy v. National Patent Systems}

The goods and services of today's global economy often travel through several continents before reaching their final destination. ${ }^{2}$ Components of a product may originate from all corners of the world; the product may be assembled in a different location; and the final product may be sold in yet another location only to be shipped anywhere in the world. Despite the increasingly global development of markets around the world, patent protection - the right to exclude others from making, using, offering for sale,

* J.D. Candidate, May 2011, University of Pittsburgh School of Law; B.S., Mechanical Engineering, University of Notre Dame, 2008. I would like to thank the board and staff of the Journal of Law and Commerce for their hard work and careful review, Professor Michael Madison for his guidance and feedback, and my parents and siblings for their love and support throughout all my endeavors.

1. Cardiac Pacemakers, Inc. v. St. Jude Medical, Inc., 576 F.3d 1348 (Fed. Cir. 2009).

2. See Elizabeth M.N. Morris, Territorial Impact Factors: An Argument for Determining Patent Infringement Based Upon Impact on the U.S. Market, 22 SAnta Clara Computer \& High TeCH. L.J. 351, 351 (2006). 
selling, or importing a new, useful, and non-obvious invention ${ }^{3}$ - is granted by individual countries and is generally only enforced within the territory of each granting country. ${ }^{4}$ In other words, patent laws are territorial rather than extraterritorial. Consequently, patent owners must operate within many different territorial patent systems to protect their inventions.

The territorial limit of a patent results in large expenses for patent owners who must "anticipate the varying levels of protection and attempt to maximize their opportunities on a country-by-country basis" by prosecuting patent applications in multiple patent systems and potentially litigating parallel patents in multiple jurisdictions. ${ }^{5}$ International agreements, such as the Agreement on Trade-Related Aspects of Intellectual Property Rights (hereinafter "TRIPS"), have begun to harmonize patent laws between member states by setting minimum levels of protection. ${ }^{6}$ Despite the harmonization achieved by TRIPS, patent owners are still required to prosecute patent applications and to litigate patents in individual countries at high costs. ${ }^{7} \mathrm{~A}$ leading patent scholar predicted over a decade ago that these "[t]wo developments - the increasing interdependence of the global economy and the growing concern over the cost of multinational intellectual property rights procurement and enforcement-will make territorialism an unacceptable obstacle to international trade."

3. See 35 U.S.C. $\S \S 101,103(a), 271($ a) (2008).

4. See, e.g., Timothy R. Holbrook, Extraterritoriality in U.S. Patent Law, 49 WM. \& MARY L. REV. 2119,2123 (2008) (stating that "intellectual property rights . . . are still national in nature: a patent, copyright, or trademark only affords the owner the right to exclude within a given country's borders"); Norris, supra note 2, at 351 (asserting that "[t]raditionally, under United States law, patents have been given only territorial application").

5. Holbrook, supra note 4, at 2123. See Mark A. Lemley, Rational Ignorance at the Patent Office, 95 Nw. U. L. Rev. 1495, 1498, 1502 (2001) (stating "[p]rosecuting patents is expensive. There is some disagreement on precisely how expensive it is, but the general range of costs for prosecuting a patent from start to finish (including application and various filing fees paid to the PTO, and attorney's fees not only to prepare and file the application, but to respond to office actions and continue prosecution through to issuance or abandonment) appears to be $\$ 10,000$ to $\$ 30,000$ per patent." And further stating in regards to patent litigation " $[w]$ hen patent litigation does occur, it is expensive. The American Intellectual Property Law Association reports, based on a survey of its members, that the median cost of patent litigation to each side is $\$ 790,000$ through the end of discovery, and $\$ 1,503,000$ through trial and appeal" (citing AIPLA Report of Economic Survey (of U.S. IP Practitioners) (1999))).

6. Agreement on Trade-Related Aspects of Intellectual Property Rights, Apr. 15, 1994, Marrakesh Agreement Establishing the World Trade Organization, Annex 1C, 33 I.L.M. 1197 (1994).

7. See Donald S. Chisum, Comment, Normative and Empirical Territoriality in Intellectual Property: Lessons from Patent Law, 37 VA. J. INT'L L. 603, 605-06 (1997).

8. Id. at 616 . 


\section{B. 35 U.S.C. $\S 271(f)$ 's Extraterritorial Reach}

There are limited exceptions to the territorial limit of patent laws. Specifically, 35 U.S.C. $§ 271(f)$ provides that a patent may be infringed when a component or components of the patented invention are supplied from the United States and shipped abroad for assembly. ${ }^{9}$ The first subpart of Section 271(f) mirrors the inducing infringement provision of Section 271(b) requiring the supply of a substantial portion of components from the United States and the inducement of the combination of the components outside the United States into the patented invention. ${ }^{10}$ The second subpart of Section 271(f) applies when a component especially made for the patented invention and not a staple article is supplied from the United States knowing and intending that the component will be combined outside the United States to form the patented invention. ${ }^{11}$ This subpart mirrors Section 271(c), the contributory infringement provision. ${ }^{12}$

C. Confusion in the Courts: Varied Approaches to Applying 35 U.S.C. $\S 271(f)$

The Supreme Court has followed a strict territorial rule and has not extended United States patent law extraterritorially without a clear signal from

9. 35 U.S.C. § 271(f) (2008):

(1) Whoever without authority supplies or causes to be supplied in or from the United States all or a substantial portion of the components of a patented invention, where such components are uncombined in whole or in part, in such manner as to actively induce the combination of such components outside of the United States in a manner that would infringe the patent if such combination occurred within the United States, shall be liable as an infringer.

(2) Whoever without authority supplies or causes to be supplied in or from the United States any component of a patented invention that is especially made or especially adapted for use in the invention and not a staple article or commodity of commerce suitable for substantial noninfringing use, where such component is uncombined in whole or in part, knowing that such component is so made or adapted and intending that such component will be combined outside of the United States in a manner that would infringe the patent if such combination occurred within the United States, shall be liable as an infringer.

10. 35 U.S.C. $\$ 271($ b) (2008) ("Whoever actively induces infringement of a patent shall be liable as an infringer.”); 35 U.S.C. § 271(f)(1) (2008).

11. 35 U.S.C. $\$ 271(\mathrm{f})(2)$.

12. 35 U.S.C. $\$ 271$ (c) (2008) ("Whoever offers to sell or sells within the United States or imports into the United States a component of a patented machine, manufacture, combination, or composition, or a material or apparatus for use in practicing a patented process, constituting a material part of the invention, knowing the same to be especially made or especially adapted for use in an infringement of such patent, and not a staple article or commodity of commerce suitable for substantial noninfringing use, shall be liable as a contributory infringer."). 
Congress. ${ }^{13}$ However, some courts have broadly construed United States patent law to protect United States patent owners even when Congress has not explicitly rebutted the presumption of territoriality. ${ }^{14}$ According to one scholar, "recent cases show that Congress is not acting expediently in closing new perceived loopholes that are arising in [patent] protection." 15 As a result, some courts "have been willing to step up and extend the extraterritorial reach of U.S. patents in ways that are shockingly different from the reticence expressed in the past." ${ }^{\prime 16}$

Courts stretch the limits of the territoriality principle under the so-called effects-based test, which "permit[s] the patent to cover acts occurring outside the United States" when there is "any effect on the U.S. market." may look for an economic effect on the United States market or an aspect of the technology that is within the United States. ${ }^{18}$ In extending the extraterritorial effect of 35 U.S.C. $\S 271$ (f), the Federal Circuit held at one time that "every form of invention eligible for patenting falls within the protection of section 271(f)," including method claims for software. ${ }^{19}$ The most recent cases, however, from both the Supreme Court and the Federal Circuit have limited the extraterritorial extension of Section 271(f). ${ }^{20}$

The varied approaches by the courts - either applying a strict territorial rule to limit the application of 35 U.S.C. § 271(f) or applying an effects-based test to expand the extraterritorial application of the statute- have confused the current state of the law. According to one scholar, "the current state of the law is unclear and lacks a firm theoretical foundation. The courts have failed to articulate a persuasive jurisprudence for assessing the extraterritorial reach of U.S. patent rights." ${ }^{21}$ As a result of the confusion, patent owners are less able to value their patents and determine the strength of their position when

13. See, e.g., Brown v. Duchesne, 60 U.S. 183, 195-96 (1856); Microsoft Corp. v. AT\&T Corp., 550 U.S. 437, 440 (2007); Deepsouth Packing Co. v. Laitram Corp., 406 U.S. 518 (1972).

14. See Kendra Robins, Extraterritorial Patent Enforcement and Multinational Patent Litigation: Proposed Guidelines for U.S. Courts, 93 VA. L. REv. 1259, 1266 (2007) (asserting "[a]lthough the text of Section[] 271(f) ... seemingly limits these statutes' extraterritorial reach by requiring some nexus between the foreign conduct and the conduct occurring in the United States, recent cases illustrate that the Federal Circuit has been willing to stretch the text of these statutes in order to find such a connection.").

15. Holbrook, supra note 4, at 2127.

16. Id.

17. Holbrook, supra note 4, at 2119-20; see Norris, supra note 2, at 352.

18. Holbrook, supra note 4, at 2155.

19. Eolas Techs., Inc. v. Microsoft Corp., 399 F.3d 1325, 1339, 1341 (Fed. Cir. 2005).

20. Microsoft Corp. v. AT\&T Corp., 550 U.S. 437, 458-59 (2007); Cardiac Pacemakers, Inc. v. St. Jude Med., Inc., 576 F.3d 1348 (Fed. Cir. 2009).

21. Holbrook, supra note 4, at 2127. 
confronted with or asserting infringement allegations. In the midst of this problematic confusion, Cardiac Pacemakers arrived in the Federal Circuit.

\section{The Cardiac Pacemakers Decision}

The Federal Circuit's Cardiac Pacemakers opinion jolted the fluctuating state of the law by limiting the extraterritorial effect of Section 271(f) for a category of patent claims - method claims. ${ }^{22}$ Holding, en banc, that Section 271(f) does not apply to method claims, the Federal Circuit's decision explicitly overruled its own precedent. ${ }^{23}$ Conceivably, the Cardiac Pacemakers decision will result in a more consistent application of 35 U.S.C. $\S 271$ (f) for future cases. However, the decision has important implications for the international community, United States industry, and owners of United States method patents. The Federal Circuit's limitation on Section 271(f) likely necessitated a legislative amendment to Section 271 of the Patent Act in order to protect method patents.

This note provides a thorough analysis of the Cardiac Pacemakers decision. Part II discusses the historical and legal background leading up to the Federal Circuit granting en banc rehearing on the case. The procedural history of the Cardiac Pacemakers case, the en banc majority's reasoning for overturning its own prior ruling, and Judge Newman's lone dissent are laid out in Part III. Finally, Part IV discusses the policy implications of Cardiac Pacemakers to the international community, United States industry and owners of United States method patents. Furthermore, Part IV argues that a legislative amendment is necessary to protect United States method patents in situations paralleling the newly created loophole of Cardiac Pacemakers.

\section{The Historical and Legal Background of CardiaC PaCemakers}

While the critical statutory language interpreted in Cardiac Pacemakers was not enacted until 1984, a thorough analysis of the decision begins with a discussion of territoriality in United States patent law.

22. Cardiac Pacemakers, 576 F.3d at 1365.

23. Id. 


\section{A. The Presumption Against Extraterritoriality}

Territoriality is " $[\mathrm{t}]$ he principle that a nation has the right of sovereignty within its borders." ${ }^{24}$ According to Professor Goldstein, three maxims are incorporated into the principle of territoriality: (1) a state's laws should only have force within that state's borders, (2) anyone within the state's boundaries is subject to the laws of that state, and (3) comity should "discipline sovereign exercises of authority so that the territorial effect of each state's laws is respected." ${ }^{25}$ As stated by the United States Supreme Court, the "legislation of Congress, unless a contrary intent appears, is meant to apply only within the territorial boundaries of the United States. ${ }^{.26}$ In other words, there is a presumption of territoriality, which can only be overcome when "the affirmative intention of Congress [is] clearly expressed."27

Throughout analyses pertaining to the territoriality principle, the Supreme Court has justified the presumption of territoriality on five different grounds: international law, international comity, choice of law principles, congressional intent, and separation of powers considerations. ${ }^{28}$ Generally, applying United States patent law extraterritorially is negatively perceived because it fails to consider the policies and sovereignty of foreign countries. ${ }^{29}$ For example, when the Federal Circuit in NTP v. Research in Motion failed to consider the interests of Canada regarding alleged acts of infringement within Canada, the Canadian government expressed frustration with the American court for the unilateral assertion of United States patent law abroad. ${ }^{30}$ Despite the

24. Black's Law Dictionary 1610 (9th ed. 2009).

25. Id. (quoting Paul Goldstein, International Copyright: Principles, Law, and Practice $64(2001))$.

26. Foley Bros. v. Filardo, 336 U.S. 281, 285 (1949).

27. Benz v. Compania Naviera Hidalgo, S.A., 353 U.S. 138, 147 (1957).

28. William Greubel, Note, A Comedy of Errors: Defining "Component" in a Global Information Technology Market-Accounting for Innovation by Penalizing the Innovators, 24 J. MARSHALL J. COMPuter \& INFo. L. 507, 512 (2006) (citing Curtis A. Bradley, Extraterritorial Application of U.S. Intellectual Property Law: Principal Paper: Territorial Intellectual Property Rights in an Age of Globalism, 37 VA. J. INT'L LAw 505, 513-14 (1997)) (stating that although no definite account exists, a review of the Supreme Court's extraterritorial decisions reveals that over time these five justifications have been articulated).

29. See Holbrook, supra note 4, at 216; Dariush Keyhani, Patent Law in the Global Economy: A Modest Proposal for U.S. Patent Law and Infringement without Borders, 54 VILL. L. REV. 291, 292 (2009) ("Creating liability under U.S. law for activities that do not violate the domestic laws of the places where the activity occurs is contrary to basic presumptions of all major international treatises on intellectual property law and principles of comity.").

30. Brief for the Government of Canada as Amicus Curiae Supporting the Petition Respondents, NTP, Inc. v. Research in Motion, Ltd., 418 F.3d 1282 (Fed. Cir. 2005) (No. 03-1615) ("The reissued panel 
substantial harmonization of patent laws throughout the world as a result of the TRIPS agreement, differences between patent systems remain, and the extraterritorial extension of United States patent law disregards these differences. ${ }^{31}$ Consequently, such extraterritorial application of United States patent law is ill-perceived by the international patent community.

Though the extension of United States patent laws extraterritorially may be problematic to international laws, international comity, choice of laws, congressional intent, and separation of powers, the failure to extend United States patent laws extraterritorially can hurt United States patent owners. ${ }^{32}$ For example, prior to the enactment of 35 U.S.C. § 271(f), a company could avoid infringement liability by manufacturing all the components of a patented invention in the United States and then shipping the components overseas for final assembly. ${ }^{33}$ This loophole in the enforcement of patents left patent owners in a defenseless position. The new loophole created by Cardiac Pacemakers leaves method patent owners vulnerable to competitors who may manufacture physical components in the United States, which may be used to practice a patented method, and then induce use of the patented method outside the United States.

Congressional decisions to extend United States patent law extraterritorially, such as 35 U.S.C. $§ 271(f)$, must balance countervailing concerns: the justifications for the presumption against territoriality and the needs of the United States patent system, including effects on United States

opinion lacks any acknowledgment or discussion of the effect of, or the effect upon, long-established international understandings and agreements regarding national jurisdiction over intellectual property.... Explicit articulation of such principles will not merely facilitate the evolution of international intellectual property law, nor simply satisfy the Supreme Court's admonition ... to address such matters in statutory construction analyses when potential issues of extraterritoriality are implicated, but also avoid what otherwise could appear to some as a unilateral assertion of patent infringement jurisdiction, justified solely in terms of national law, over the technology of a trans-national system.").

31. For example, the United States patent system includes "higher-order living animals, computer software, and business methods" as patentable subject matter, though many other countries do not protect this subject matter. Holbrook, supra note 4, at 2164.

32. Scholars have proposed alternative solutions to protecting the United States patent owner without extraterritorially extending United States law. For example, Timothy Holbrook suggests that courts should "explicitly consider foreign law in assessing whether to enforce a patent extraterritorially" so that an alleged infringer would not be held liable under United States patent law unless he "would also infringe under the laws of the foreign country." Holbrook, supra note 4, at 2120. Kendra Robins suggests that "U.S. courts should look to the adjudication of parallel foreign patents in addition to the U.S. patent in suit." Robins argues that " $[\mathrm{i}] \mathrm{n}$ many situations, the adjudication of foreign patents serves as a practical alternative that can alleviate some of the policy concerns arising from the courts' recent constructions of Section 271(f) and (g)." Robins, supra note 14, at 1266.

33. See Deepsouth Packing Co. v. Laitram Corp., 406 U.S. 518, 531-32 (1972), discussed infra at note 50 . 
industry and United States method patent owners. The Federal Circuit's decision to limit application of Section 271(f) to non-method patents should invite Congress to reconsider these countervailing concerns for method patents. Upon reconsideration, it should be apparent that a legislative amendment to Section 271 is necessary which clearly rebuts the presumption against extraterritoriality and extends United States patent law for method patents under a provision similar to Section 271(f). Without such an amendment, method patents will remain devalued and, consequently, there will be little incentive for inventors to obtain them.

\section{B. Brown v. Duchesne: An Early Statement on the Territoriality of United States Patent Law}

Under the territoriality principle, the patent laws of the United States are presumed only to apply within the boundaries of the United States. ${ }^{34}$ This has long been a foundational principle of United States patent law. ${ }^{35}$ Brown v. Duchesne is the first reported case commenting on the territoriality of United States patent laws. ${ }^{36}$ In Brown v. Duchesne, the Supreme Court failed to find patent infringement although a French schooner with an allegedly patent infringing sail was docked in a Boston harbor under the "temporary presence doctrine." ${ }^{37}$ The Court continued in dicta with the often-cited statement on the territoriality of United States patent laws:

[T] hese acts of Congress [the Patent Statutes] do not, and were not intended to, operate beyond the limits of the United States; and as the patentee's right of property and exclusive use is derived from them, they cannot extend beyond the limits to which the law itself is confined. And the use of it outside of the jurisdiction of the United States is not an infringement of his rights, and he has no claim to any compensation for the profit or advantage the party may derive from it. ${ }^{38}$

In other words, the principle of territoriality restricts the United States from imposing United States patent laws outside the jurisdiction of the United States.

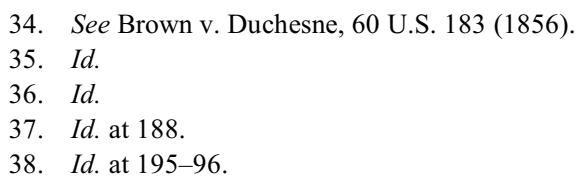


C. The Deepsouth Loophole and Enactment of 35 U.S.C. \& 271(f)

Due to the territoriality of United States patent laws, a United States patent is generally only infringed when the infringing activity occurs in the United States. ${ }^{39} 35$ U.S.C. $§ 271(\mathrm{f})$, however, is an exception to that general rule. ${ }^{40}$ Consequently, prior to the enactment of Section $271(\mathrm{f})$, manufacturers in the United States were able to easily avoid infringement liability for another's patent when manufacturing (1) "a substantial portion of the components of the patented invention" and inducing infringement of the patent outside the United States or (2) when manufacturing a non-staple component "especially made or especially adapted for use in the invention . . . knowing" and "intending" infringement of the patent outside the United States. ${ }^{41}$ The manufacturer must simply have shipped the component or components overseas for final assembly to circumvent liability.

The scenario prohibited by 35 U.S.C. $§ 271(f)(1)$ was explicitly allowed by the United States Supreme Court in Deepsouth Packing Co. v. Laitram Corp. ${ }^{42}$ In Deepsouth, components of a patented shrimp-deveining machine were manufactured in the United States and shipped overseas for assembly. ${ }^{43}$ The components were shipped in three separate boxes and could be assembled into the patented machine in less than an hour. ${ }^{44}$ Because the patented product was not made within the United States, the company expertly discovered a loophole in United States patent law and easily circumvented it. ${ }^{45}$ Specifically, without a finding of direct infringement within the United States, the Deepsouth Court could not find contributory infringement under 35 U.S.C. $\S 271(\mathrm{c}){ }^{46}{ }^{46}$ The court relied on the territoriality principle it enunciated in Brown v. Duchense to conclude that a "clear and certain signal from Congress" was necessary before the patentee could assert rights in this situation. ${ }^{47}$

39. Microsoft Corp. v. AT\&T Corp., 550 U.S. 437, 441 (2007); 35 U.S.C. § 271(a) (2006).

40. Janice M. Mueller, PAtent LAW 394 (3d ed. 2009) (“\$ 271(f) involves certain extraterritorial activities, but those activities must have a nexus to acts occurring in the United States. Where that nexus is adequately established, $\S 271(\mathrm{f})$ creates liability as an exception to the 'general rule under United States patent law that no infringement occurs when a patented product is made and sold in another country."' (quoting AT\&T II, 441 U.S. at 441)) (emphasis added).

41. 35 U.S.C. $\$ 271(f)(1)$, (2) (2008).

42. Deepsouth Packing Co. v. Laitram Corp., 406 U.S. 518 (1972).

43. Id. at 524

44. $I d$.

45. See id.

46. Id. at 526 .

47. Id. at 531 . 
Over ten years after the Court's invitation to Congress to resolve the Deepsouth loophole, 35 U.S.C. § 271(f) was enacted, which legislatively overruled the United States Supreme Court's conclusion in Deepsouth. ${ }^{48}$ Section 271(f) demonstrates a clear Congressional intent to legislate extraterritorially. ${ }^{49}$ Much of the recent discussion by courts and legal scholars focuses on whether Congress intended Section 271(f) to merely overturn the conclusion reached by the Supreme Court in Deepsouth or to have a broader extraterritorial effect. ${ }^{50}$ While application of the statute is relatively straightforward for product claims in the manufacturing and physical technologies, such as in Deepsouth, application of the statute in other contexts has been problematic. ${ }^{51}$

\section{Federal Circuit Cases Leading up to Cardiac Pacemakers}

In early cases applying 35 U.S.C. § 271(f), district courts failed to consistently interpret "component" within the statute. ${ }^{52}$ The inconsistent

48. 130 CONG. REC. H10525 (1984).

49. Foley Bros., 336 U.S. at 284.

50. Robins, supra note 14, at 1277 ("'[I]t is ambiguous whether Congress, in enacting Section 271(f) intended to merely overturn Deepsouth or whether Congress intended 271(f) to have broader extraterritorial effect.") (citing Joan E. Beckner, Patent Infringement by Component Export: Waymark Corp. v. Porta Systems Corp. and the Extraterritorial Effect of U.S. Patent Law, 39 Hous. L. Rev. 803 (2002)); Microsoft Corp. v. AT\&T Corp., 550 U.S. 437 n.18 (2007) (“Section 271(f)'s text does, in one respect, reach past the facts of Deepsouth. While Deepsouth exported kits containing all the parts of its deveining machines, $\S 271(\mathrm{f})(1)$ applies to supply abroad of 'all or a substantial portion' of the patented invention's components. And $\S 271(f)(2)$ applies to the export of even a single component if it is 'especially made or especially adopted for use in the invention and not a staple article or commodity of commerce suitable for substantial noninfringing use."”).

51. See generally James R. Farrand, Territoriality and Incentives under the Patent Laws: Overreaching Harms U.S. Economic and Technological Interests, 21 BerkeLEY TeCH. L.J. 1215 (2006).

52. For example, an early case interpreting "component" was brought before the District Court of the Eastern District of Virginia in 1998. Enpat, Inc. v. Microsoft Corp., 6 F. Supp. 2 d 537 (E.D. Va. 1998). In Enpat, the district court determined that Microsoft's foreign sales of its Microsoft Project and Microsoft Team Manager products did not infringe a patented method for a project manager system. Id. at 539. In reaching this conclusion, the district court examined the legislative history of the statute finding an "exclusive focus on the sale of components patented in the United States for combination into a finished product, apparatus, or invention abroad;" thus, the court held that § 271(f) did not apply to method patents. Id.

The following year, the District Court of Delaware reached the opposite conclusion in W.R. Grace \& Co.-Conn. v. Intercat, Inc., an infringement case involving a patented chemical composition. $60 \mathrm{~F}$. Supp. 2d 316 (D. Del. 1999). Though the opinion did not explicitly address application of Section 271(f) to method patents, the court adopted a broad interpretation of "component" in applying the statute to chemical compositions noting that "[n]owhere in the statute or its legislative history is there a limitation to components of machines and other structure combinations." Id. at 321. 
application of Section 271(f) by district courts encouraged the Federal Circuit to clarify the issue. In decisions leading up to Cardiac Pacemakers, the Federal Circuit had consistently construed "component" in Section 271(f) with increasing breadth and applied the infringement provision to a wide-variety of technologies. For example, in Eolas Techs., Inc. v. Microsoft Corp., Microsoft provided golden master discs with software code to foreign manufactures. ${ }^{53}$ The court first asserted, "every component of every form of invention deserves the protection of 271(f)." ${ }^{54}$ Because "[e]xact duplicates of the software code on the golden master disk are incorporated as an operating element of the ultimate device," Microsoft had provided a "component" under the statute and was liable as an infringer. ${ }^{55}$

In AT\&T Corp. v. Microsoft Corp. (AT\&T I), a case involving facts similar to those in Eolas, Microsoft again supplied golden master disks to foreign manufacturers. ${ }^{56}$ As in Eolas, the Federal Circuit found Microsoft liable as an infringer under Section 271(f).$^{57}$ Though the Supreme Court later reversed this holding, ${ }^{58}$ the Federal Circuit's reasoning is interesting. The court first relied on Eolas to assert that the golden master disks with Windows software - though sent abroad electronically—were "component[s] of a patented invention." ${ }^{59}$ The court then held that the disks were "supplied" from the United States within the meaning of the statute. ${ }^{60}$ Though Microsoft sent limited disks abroad, the recipients were authorized by Microsoft to copy the software and to install it on foreign-assembled computers. ${ }^{61}$ "Accordingly, for software 'components,' the court found that the act of copying is subsumed in the act of 'supplying,' such that sending a single copy abroad with the

In 2002, the District Court of New Jersey relied on the Enpat court's reasoning and asserted as a matter of law "that $\S 271$ (f) does not apply to method patents." Synaptic Pharm. Corp. v. MDS Panlabs, Inc., 265 F. Supp. $2 d$ 452, 464 (D.N.J. 2002). The method patents in this case were directed to assays that "determine whether certain chemical compounds will bind with certain proteins residing on the surface of human cell," which are useful to pharmaceutical companies in developing new drugs. Id. at 455 . These conflicting interpretations of "component" by the district courts demonstrate the early inconsistency in applying the statute outside the traditional sphere of product claims in manufacturing and physical technologies.

53. Eolas Techs., Inc. v. Microsoft Corp., 399 F.3d 1325, 1339 (Fed. Cir. 2005).

54. Id.

55. $I d$.

56. AT\&T Corp. v. Microsoft Corp., 414 F.3d 1366, 1368 (Fed. Cir. 2005).

57. $I d$.

58. Microsoft Corp. v. AT\&T Corp., 550 U.S. 437, 442 (2007).

59. $A T \& T, 414$ F.3d at 1369 .

60. Id. at 1370 .

61. Id. at 1368 . 
intent that it be replicated invoked $\S 271$ (f) liability for those foreign-made copies." 62

Finally, the Federal Circuit's holding in Union Carbide Chemicals \& Plastic Technology Corp. v. Shell Oil Co. reaffirmed the Eolas court's assertion that "every form of invention" is protected by 35 U.S.C. $\S 271(f){ }^{63}$ In Union Carbide, the contested patent claimed an improved method to produce ethylene oxide.$^{64}$ The district court held that Section 271(f) did not apply to method claims ${ }^{65}$ On appeal, however, the Federal Circuit held that the district court had erred in this finding and remanded the case. ${ }^{66}$ The court reasoned that patentable subject matter includes "any new and useful process, machine, manufacture, or composition of matter, or any new and useful improvement thereof." ${ }^{97}$ First, the court found that a process claim, also called a method claim, "consists of a series of acts or steps." ${ }^{98}$ The court then reiterated the statement from an earlier case that "the statute makes no distinction between patentable method/process inventions and other forms of patentable inventions." ${ }^{\circ 9}$ Consequently, the Federal Circuit concluded that Section 271(f) applies to all patentable subject matter and the phrase "component(s) of a patented invention" in 35 U.S.C. § 271(f) includes components of method patents - the series of steps to practice the method. ${ }^{70}$

\section{E. The Supreme Court's Effort to Resolve the Confusion}

The United States Supreme Court has also expressed an opinion concerning the proper interpretation of "component" in 35 U.S.C. $\S 271(f) .{ }^{71}$ In Microsoft Corp. v. AT\&T Corp. (AT\&T II), the Court reversed a Federal Circuit decision and drew a narrow distinction between the facts in Eolas and $A T \& T I .^{72}$ Because the foreign manufacturers made a copy of the golden master disk before installing the software into the computers, the Court

62. Id. at 1370

63. Union Carbide Chem. \& Plastic Tech. Corp. v. Shell Oil Co., 425 F.3d 1366, 1379 (Fed. Cir. 2005) (citing Eolas Techs. Inc. v. Microsoft Corp., 399 F.3d 1325, 1339 (Fed. Cir. 2005)).

64. Id. at 1370

65. Id. at 1369 .

66. Id. at 1381 .

67. Union Carbide, 425 F.3d at 1379 (interpreting 35 U.S.C. $§ 101$ (2006)).

68. In re Kollar, 286 F.3d 1326, 1332 (Fed. Cir. 2002).

69. Union Carbide, 425 F.3d at 1379.

70. Union Carbide, 425 F.3d at 1379 (citing Eolas Techs., Inc. v. Microsoft Corp., 399 F.3d 1325, 1339 (Fed. Cir. 2005)).

71. Microsoft Corp. v. AT\&T Corp., 550 U.S. 437, 440 (2007).

72. Id. at 449 n. 10 . 
considered the copy — not the golden master disk - to be the "component" within the meaning of statute. ${ }^{73}$ Microsoft provided the "golden master" disk, but not the copy so Microsoft escaped infringement liability. ${ }^{74}$ The Supreme Court concluded by affirming the presumption against extraterritoriality: "United States law governs domestically but does not rule the world" and this presumption "applies with particular force in patent law."

\section{The CARDiac PaCEMaKers Decision}

\section{A. The Background of the Cardiac Pacemakers Decision}

In Cardiac Pacemakers, the challenged claim was directed to a method of treating abnormal heart rhythms by determining the heart condition, selecting cardioversion as the appropriate therapy, and executing a cardioverting shock with an implantable cardiovascular defibrillator (ICD).$^{76}$ Cardiac Pacemaker alleged that a competitor produced ICDs in the United States that were capable of performing the patented method and exported these ICDs abroad. ${ }^{77}$ Cardiac Pacemaker argued that the ICDs were components of the patented method claim under 35 U.S.C. $\S 271$ (f) and, thus, that the exportation of these "components" violated Section 271(f) ${ }^{78}$

Cardiac Pacemakers followed a circuitous route to the Federal Circuit's en banc opinion. ${ }^{79}$ Upon reaching the en banc Federal Circuit, the court

73. Id. at 453 .

74. Id.

75. Id. at 454-55.

76. Cardiac Pacemakers, Inc. v. St. Jude Med. Inc., 576 F.3d 1348, 1352 (Fed. Cir. 2009).

77. $I d$.

78. Id. at $1364-65$.

79. In the initial action before the district court, the jury found that St. Jude Medical infringed Cardiac Pacemakers' patent and awarded Cardiac Pacemaker $\$ 140$ million in royalties. Cardiac Pacemakers, Inc. v. St. Jude Med., Inc., No. IP 96-1718-CH/K (S.D. Ind. 2002). However, the District Court overturned this verdict, granted a new trial, and granted judgment as a matter of law on invalidity and noninfringement to St. Jude. Id.

Cardiac Pacemaker appealed the district court's judgment, and the Federal Circuit affirmed in part and modified in part the district court's claim construction, reinstated the jury verdict on validity, and remanded for a new trial on the issues of infringement and damages. Cardiac Pacemakers, Inc. v. St. Jude Med., Inc., 381 F.3d 1371 (Fed. Cir. 2004). St. Jude's motions for rehearing, rehearing en banc, and certiorari were denied. Id., St. Jude Med., Inc. v. Cardiac Pacemakers, Inc., 544 U.S. 1032 (2005).

On remand, the court's "Damages Decision" limited damages to ICDs that "executed the claimed method of cardioversion during the relevant infringement period," but did not limit damages to ICD's sold in the United States because those sold abroad could infringe the claimed method under 35 U.S.C. § 271(f). Cardiac Pacemakers, Inc. v. St. Jude Med., Inc., 418 F. Supp. 2d 1021 (Fed. Cir. 2006). The district court then permitted damages and granted Cardiac Pacemakers' motion for Summary Judgment of Infringement, 
limited application of 35 U.S.C. $\S 271$ (f) to non-method claims and reversed the earlier ruling. ${ }^{80}$ Consequently, the court held that St. Jude's ICDs, which executed the patented method outside the United States did not infringe Cardiac Pacemakers' method patent. ${ }^{81}$

\section{B. The Federal Circuit's En Banc Majority}

The court's analysis considered the language of 35 U.S.C. § 271(f), case law, Webster's Dictionary, the context of the statute in the Patent Act, and the legislative history of the statute. The en banc majority first distinguished components of method patents from components of non-method patents for infringement liability purposes. $^{82}$ This critical distinction ultimately "doom[ed] Cardiac's argument" that the ICD was a component of the patented invention. ${ }^{83}$ The components of a method patent are the steps in the method; the components of non-method patents are "tangible items." relying on case law $^{85}$ and Webster's Dictionary, ${ }^{86}$ the en banc majority concluded that the intangible steps of method patents - not the physical components used to perform the method-are the "components" of the patented invention within the "definitional requirement" of Section 271(f) ${ }^{87}$

but also granted St. Jude's motion for Summary Judgment for anticipation. Cardiac Pacemakers, Inc. v. St. Jude Med., Inc., 483 F. Supp. 2d 734 (S.D. Ind. 2007). The parties cross-appealed. Id.

The Federal Circuit on appeal affirmed the district's court limitation on damages to ICDs sold abroad under 35 U.S.C. $\S 271(\mathrm{f})$, reversed the district court's summary judgment of invalidity by anticipation, reinstated the jury's verdict of validity and enforceability, reversed the grant of a conditional new trial on the issue of unenforceability, and remanded for a determination of damages. Cardiac Pacemakers, Inc. v. St. Jude Med., Inc., 303 Fed. Appx. 884, 2008 WL 5257333 (Fed. Cir. 2008). The parties petitioned for rehearing and rehearing en banc. Id. St. Jude's petition for rehearing en banc was granted. Cardiac Pacemakers, Inc. v. St. Jude Med., Inc., 315 Fed. Appx. 273, 2009 WL 596010 (C.A. Fed. (Ind.)).

80. Cardiac Pacemakers, 576 F.3d at 1365.

81. Id. Further, the court reversed the district court's grant of summary judgment of invalidity and reinstated the jury verdict of validity. $I d$. at 1366 . The court also reinstated the jury verdict finding the patent not unenforceable for inequitable conduct and reversed the district court's grant of a conditional new trial on the issue. Id. Finally, the case was remanded for a determination of damages. Id. Subsequent to the remand, the Supreme Court denied a petition for writ of certiorari. Cardiac Pacemakers, 130 S. Ct. 1088 (2010).

82. Cardiac Pacemakers, Inc. v. St. Jude Med., Inc., 576 F.3d 1348, 1362 (Fed. Cir. 2009).

83. $I d$.

84. $I d$.

85. Id. at 1363 .

86. Id. (citing Webster's Third New International Dictionary of the English Language 466 (1981) (““Component' is defined as 'a constituent part,' 'element,' or 'ingredient.'”)).

87. Cardiac Pacemakers, 576 F.3d at 1363. 
The en banc majority distinguished the Supreme Court's statement in Quanta Computer, Inc. v. LG Electronics, Inc. that "[a]pparatus and method claims may approach each other so nearly that it will be difficult to distinguish the process from the function of the apparatus. ${ }^{" 88}$ The court reasoned that this statement was in the context of patent exhaustion where the sale or license of a product reasonably compensates the patent owner whether or not the patent claimed a product or a method ${ }^{89}$ While the distinction may be blurred when determining patent exhaustion, the en banc majority emphasized the clarity of the distinction in establishing patent infringement. ${ }^{90}$

The en banc majority found additional support for its characterization of method patent components in Section 271(c), the contributory infringement provision of the Patent Act. ${ }^{91}$ The en banc majority relied on the contrast between "a component of a patented machine, manufacture, combination, or composition" and "a material or apparatus for use in practicing a patented process" in Section 271(c) to decipher the legislature's belief that components are distinguishable from "a material or apparatus" that practices a patented method..$^{92}$ From this inference, the en banc opinion reiterated that an apparatus or material used to practice a patented invention, like the ICD in Cardiac Pacemakers' patent, is not a component under Section 271(f). ${ }^{93}$

After characterizing a method patent component as a step in the patented method, the en banc opinion turned to the term "supply" in 35 U.S.C. $\S 271(\mathrm{f}) .{ }^{94}$ Relying on simple logic, ${ }^{95}$ in addition to case law, ${ }^{96}$ and Webster's Dictionary, ${ }^{97}$ the en banc majority determined that only physical objects can

88. Quanta Computer, Inc. v. LG Electronics, Inc., 553 U.S. 617, 629 (2008).

89. Cardiac Pacemakers, 576 F.3d at 1362-63.

90. Id. at 1363 .

91. Id. at 1363-64; 35 U.S.C. § 271(c) (2006) (Contributory liability attaches to "[w]hoever offers to sell or sells within the United States or imports into the United States a component of a patented machine, manufacture, combination, or composition, or a material or apparatus for use in practicing a patented process, constituting a material part of the invention, knowing the same to be especially made or especially adapted for use in an infringement of such patent, and not a staple article or commodity of commerce suitable for substantial noninfringing use.").

92. Cardiac Pacemakers, 576 F.3d at 1363-64.

93. Id.

94. Id. at 1364

95. Id. (stating "[s] upplying an intangible step is thus a physical impossibility ....").

96. NTP, Inc. v. Research in Motion, Ltd., 418 F.3d 1282, 1322 (Fed. Cir. 2005) ("[I]t is difficult to conceive how one might supply or cause to be supplied all or a substantial portion of the steps in the patented method in the sense contemplated by ...." Section 271(f).).

97. Cardiac Pacemakers, 576 F.3d at 1364 (quoting Webster's Third New International Dictionary On THE English LANGUAGe 2297 (1981) (“The ordinary meaning of 'supply' is to 'provide that which is required,' or 'to furnish with ... supplies, provisions, or equipment."')). 
be supplied. ${ }^{98}$ Consequently, by nature of the characterization of a method patent "component" as a step of the patented method - an intangible "component"-it cannot be supplied; thus, Section 271(f) "cannot apply to method ... patents." 99

The Federal Circuit majority next reviewed the legislative history of 35 U.S.C $\S 271$ (f) to find support for limiting the scope of the statute. ${ }^{100}$ The en banc opinion noted that the statute was explicitly enacted to close the loophole in Deepsouth, a case involving an apparatus patent. ${ }^{101}$ Additionally, the majority found that "Congress's focus on patented products" throughout the legislative history and the minimal reference to protecting method patents further supported their position. ${ }^{102}$

Finally, the en banc majority reiterated the "presumption against extraterritoriality," which had been recently reaffirmed by the Supreme Court in $A T \& T I I .{ }^{103}$ The majority concluded that the limited extension of United States patent law by Section 271(f) should not be further extended to method patents without clear congressional intent. ${ }^{104}$

\section{The Lone Dissenter: Judge Newman}

Judge Newman dissented from the en banc holding that 35 U.S.C. $\S 271(\mathrm{f})$ did not apply to method patents. ${ }^{105}$ Judge Newman reached her contrary opinion by focusing on the text and context of Section 271(f), as well as the legislative history. Judge Newman's dissent first argued that it was an "extreme redefinition" to define "patented invention" within Section 271(f) to exclude method patents. ${ }^{106}$ Relying on precedent from the Supreme Court and Federal Circuit, Judge Newman asserted that the first canon of statutory interpretation is the presumption "that a legislature says in a statute what it means and means in a statute what it says." ${ }^{107}$ Further, when a statute is unambiguous - as Judge Newman asserts is the case for Section 271(f) - then

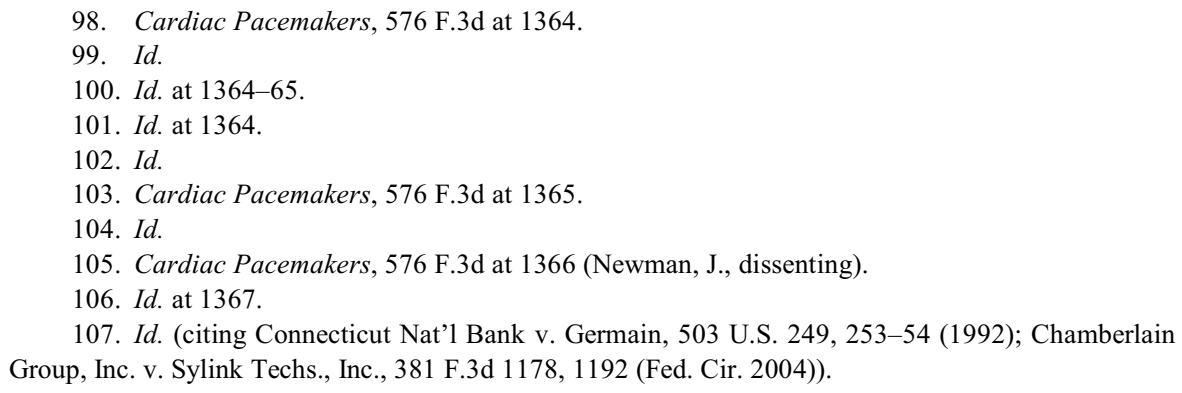


"judicial inquiry is complete." ${ }^{108}$ Based on the plain wording of the statute; ${ }^{109}$ the definition of "patented invention" in Section 101 of the Patent Act: ${ }^{110}$ and the Supreme Court's holding in Eli Lilly \& Co. v. Medtronic, Inc. that "patented invention" in Section 271(e), an adjacent infringement provision enacted just six weeks prior to the enactment of Section 271(f), should be "defined to include all inventions," 111 Judge Newman found that "patented invention" in Section 271(f) unambiguously includes method patents. ${ }^{112}$

Judge Newman found additional support for her opinion by analyzing the statute within the context of Title 35 and the legislative history. She recognized a pattern throughout each provision of Section 271 "recit[ing] its subject matter with generality or specificity, as appropriate."113 Additionally, she noted that the subject matter of Sections $271(\mathrm{c}),{ }^{114}$ (e),${ }^{115}$ (f), and $(\mathrm{g})^{116}$ reflects the legislature's intent to enact infringement provisions directed to specific subject matter. ${ }^{117}$

Turning to the legislative history, Judge Newman observed that an initial version of the statute limited the subject matter to "a patented machine, manufacture, or composition of matter." 118 Because the enacted statute broadened the subject matter to "patented invention[s]," Judge Newman concluded that this "demonstrates the purposeful action to include processes in $\S 271(f)$, instead of the more limited scope of earlier versions of the legislation." 119

Towards the conclusion of her dissent, Judge Newman addresses public policy concerns. ${ }^{120}$ She first dismisses extraterritoriality concerns because "[1]iability under $\S 271(\mathrm{f})$ is based on domestic conduct and intent." Consequently, the statute does not violate territoriality principles. ${ }^{122}$

108. Id. at 1367 . 2004)).

109. Id. (citing Chamberlain Group, Inc. v. Skylink Techs., Inc., 381 F.3d 1178, 1192 (Fed. Cir.

110. Id. at $1367-68$.

111. See Eli Lilly \& Co. v. Medtronic, Inc., 496 U.S. 661, 665 (1990).

112. Cardiac Pacemakers, 576 F.3d at 1368 (Newman, J., dissenting).

113. $I d$.

114. 35 U.S.C. $\S 271$ (c) (2006) (“a patented machine, manufacture, combination, or composition, or ... a patented process").

115. 35 U.S.C. § 271(e) (2006) (“a patented invention”).

116. 35 U.S.C. $\$ 271$ (g) (2006) (“a process patented”).

117. Cardiac Pacemakers, 576 F.3d at 1369 (Newman, J., dissenting).

118. Id. at 1370 (citing S. 2504, 93d Cong. (1974)).

119. Id.

120. Id. at 1373 .

121. $I d$.

122. Id. 
Additionally, she acknowledges the potentially unfair effect of the statute on United States businesses, but still asserts that the en banc majority "overreacted as well as overreached" in limiting application of the statute to nonmethod patents. ${ }^{123}$

\section{IMPLiCATIONS OF CARDIAC PACEMAKERS}

The implications of the Federal Circuit's en banc decision in Cardiac Pacemakers relate to various dimensions of the patent system including the international patent community, United States businesses, and owners of United States method patents. Upon review of the costs and benefits of the decision, it is recommended that Congress amend Section 271 of the Patent Act to protect United States method patent owners under a provision similar to Section 271(f).

\section{A. Costs and Benefits of the Holding on Various Dimensions of the Patent System}

\section{Impact on International Extraterritoriality Concerns}

Prior to the Cardiac Pacemakers decision, United States courts had increasingly broadened the application of 35 U.S.C. $\S 271(\mathrm{f})$, thus increasing international extraterritoriality concerns. Though Section 271(f) still remains intact for non-method patents after Cardiac Pacemakers, the creation of a loophole for method patents reduces the scope of the statute. Consequently, the international patent community's extraterritoriality concerns are reduced.

Arguably, however, Section 271(f) may not even invoke strong concerns related to extraterritoriality. Judge Newman's dissent in Cardiac Pacemakers argued that Section 271(f) does not violate any of Professor Goldstein's principles of territoriality. ${ }^{124}$ Arguably, infringement under Section 271(f) does not result from any acts abroad. Rather, infringement requires "some domestic act as a hook to reach foreign-based economic activity that harms a patent owner's interest in deriving full economic advantage from the U.S.

123. Id. at 1374 .

124. Id. at 1373 (" $[\mathrm{T}]$ he statutory purpose [of Section 271(f)] is to reach the evasion of United States rights by actions that are taken within the United States by entities subject to United States law. The practice of foreign countries of United States-origin technology without any contribution of components from the United States is untouched by $\S 271$ (f), whether of process or product. Liability under $\S 271(\mathrm{f})$ is based on domestic conduct and intent."); see GoldsteIn, supra note 25. 
market for the patented invention." ${ }^{125}$ In Waymark Corp. v. Porta Systems Corp., the Federal Circuit held that Section 271(f) does not require evidence of actual assembly abroad. ${ }^{126}$ Rather, the critical elements to find infringement liability under Section 271(f) are the supply of components from the United States with intent to combine the components into the patented invention. These elements relate to conduct and culpability within the United States. Therefore, while Cardiac Pacemakers reduces extraterritoriality concerns related to Section 271(f), the legitimacy of these concerns is unclear.

\section{Impact on United States Businesses}

Additionally, the Cardiac Pacemakers decision has important implications for United States businesses. 35 U.S.C. § 271(f) arguably undermines the capacity of U.S. companies to compete in the U.S. market for the patented invention against other companies located abroad. ${ }^{127}$ Specifically, a United States company that ships components of a patented invention abroad for final assembly may be found liable for infringement under Section 271(f). Comparatively, a foreign company or an American company with facilities abroad that manufactures the same components for assembly into the patented invention cannot be found liable under Section 271(f). Therefore, American companies are discouraged from producing goods and services in the United States. Innovators may move Research and Development facilities and manufacturing facilities overseas in order to avoid increased liability for infringement. ${ }^{128}$ The movement of additional American companies' facilities overseas could hurt the United States economy and reduce the availability of jobs for Americans. Arguably, the exclusion of method patents from the scope of Section 271(f) counterbalances the movement of United States facilities overseas because domestic companies will not be subject to infringement liability when exporting the components that are used to practice a patented method.

\section{Impact on United States Patent Owners}

The recent Cardiac Pacemakers decision appears to benefit United States businesses by limiting infringement liability. However, limiting application

125. Chisum, supra note 7, at 607.

126. Waymark Corp. v. Porta Sys. Corp., 245 F.3d 1364, 1368 (Fed. Cir. 2001).

127. See Holbrook, supra note 4.

128. See Farrand, supra note 51, at 54. 
of 35 U.S.C. § 271(f) to non-method patents will simultaneously hurt United States method patent owners. The newly created loophole allows for easy circumvention of liability for method patent infringement, which will often leave method patent owners without a remedy. Companies like St. Jude Medical can now avoid infringement liability simply by exporting parts used to practice a patented method. Consequently, the value of method claims is reduced. ${ }^{129}$ It is likely that patent prosecutors will cease drafting devalued method claims when an alternative apparatus claim protects the invention and remains enforceable under Section 271(f).

Interestingly, there is a large overlap between those who appear to benefit - largely the United States industries who have decreased infringement liability when manufacturing components used to practice a patented method-and those who will be hurt-United States companies who own valuable method patents - by the Cardiac Pacemakers decision. Robust intellectual property rights are characteristic of the United States patent system. Rigorous enforcement of such rights in the United States is generally supported by business that own United States method patents, which they want to protect. Though conceivably many United States businesses may face increased infringement liability post-Cardiac Pacemakers, many United States businesses will also be unable to enforce their method patents in the United States and will be left without a remedy as in Cardiac Pacemakers.

\section{B. Likelihood and Necessity of a Legislative Amendment}

After the Federal Circuit's Cardiac Pacemakers decision, the American software company that designs software in the United States and then sends the software code abroad for the mass production of copies, is only liable for infringement of the United States patent if the patent claimed an apparatus, such as a computer, that used the software. A United States patent claiming the software as a method would not be infringed under Section 271(f). This convoluted result dramatically hurts United States method patent owners.

In the wake of the Supreme Court's ruling in Deepsouth, Congress stepped forward with a legislative amendment to close the Deepsouth loophole. Perhaps the Cardiac Pacemakers decision indicates that another legislative amendment is necessary. Several factors currently affecting the application of Section 271(f) were unforeseen at the time the provision was

129. See Cardiac Pacemakers, 576 F.3d at 1373 (Newman, J., dissenting) (“A statutory interpretation that results in all process inventions being seriously devalued, is not free of the charge of 'absurd result."'). 
enacted. For example, "changes in technology and increases in the crossborder movement of goods" affect the rights of United States patent owners. Arguably, these changes "teed this issue up for judicial and legislative reform." 130

A complete repeal of Section 271(f) was proposed in the 2006 Patent Reform Act. ${ }^{131}$ However, the proposal was withdrawn because $A T \& T$ II was pending for decision before the Supreme Court and it was considered more appropriate to leave the statute intact so that the judicial branch could properly interpret the statute and resolve the issue. ${ }^{132}$ It was suggested, "with its decision in Microsoft v. AT\&T, the Supreme Court resolved the principle concern over section 271(f) and eliminated the need for legislative reform." ${ }^{133}$ However, Cardiac Pacemakers indicates that the Supreme Court did not resolve all the issues related to Section 271(f). While it is likely that Cardiac Pacemakers resolved the ambiguities of Section 271(f), the resolution leaves United States method patent owners in a defenseless position that necessitates further action by Congress.

Congress should close the method patent loophole created by Cardiac Pacemakers by adding another infringement provision to Section 271. For example, an infringement provision could create liability when United States manufacturers export tangible components used in the practice of a patented method knowing and intending the patented method to be practiced abroad. Ultimately, Congress must weigh the economic and extraterritorial concerns of an additional infringement provision applicable to method patents with the breadth of rights necessary for method patent owners.

In consideration of extraterritoriality concerns, Congress should enact a statute where liability is contingent on conduct and culpability within the United States. When liability stems from acts entirely within the United States, concerns related to extraterritoriality are not very relevant. The court should also consider the economic concerns related to United States businesses and method patent owners. Arguably, some United States businesses may be hurt by the increased infringement liability under the

130. William C. Rooklidge \& Alyson G. Barker, Reform of a Fast-Moving Target: The Development of Patent Law Since the 2004 National Academies Report, 91 J. Pat \& TRAdemark Off. Soc'y 153, 167 (2009).

131. Patent Reform Act of 2006, S. 3818, 109th Cong. § 5 (2d Sess. 2006).

132. Rooklidge \& Barker, supra note 130, at 168 n.99 (citing Sen. Patrick Leahy, On Introduction of the Patent Reform Act of 2007, Apr. 18, 2007 (“[w]e do not inject Congress into the ongoing litigation over ... section 271(f) ... while the interpretation of the provision is currently pending before the Supreme Court")).

133. Rooklidge \& Barker, supra note 130, at 168. 
proposed amendment. However, many businesses will also benefit from the strengthened enforcement mechanisms for their method patents.

Congress may also consider whether the increased value in method patents under the proposed amendment is necessary in view of the purposes of the patent system. The patent right - the right to a limited monopoly over the invention - is intended to provide an economic incentive for innovators. The economic rationale for patent monopolies or "exclusive right[s]" is present in the United States Constitution, which provides: "Congress shall have power to ... promote the progress of science and useful arts, by securing for limited times to authors and inventors the exclusive right to their respective writings and discoveries." 134 Thus, Congress must determine the breadth of patent protection necessary to encourage innovation and to "promote the progress of science and useful arts." The Patent Act's infringement provisions should correspond to the necessary scope of patent protection. For example, Section 271(f) provides a larger incentive for innovators by granting a broad monopoly right that extends beyond merely protecting their invention when the patented invention is made, used, sold, or offered for sale in the United States. ${ }^{135}$ Whether an additional provision is necessary in view of the Cardiac Pacemakers loophole to encourage innovation related to method patents is debatable and an important issue for Congress to balance with the concerns of American businesses and international extraterritoriality concerns.

\section{CONCLUSION}

The Federal Circuit's interpretation of Section 271(f) of the Patent Act in Cardiac Pacemakers severely limits the scope of patent protection afforded to United States method patent owners. The decision creates a new loophole in American patent law where infringement of method patents is easily circumvented, thus drastically devaluing method patents. Congress must

134. U.S. Const. art. $1, \S 8$.

135. But see Gruebel, supra note 28, at 526-27 ("Section 271(f), however, fails to provide . . positive incentives, and in actuality only serves to stifle U.S. technological innovation for three reasons. First, 271(f) provides no meaningful prospect of protection against competition, or even 'the right to exploit [an] invention' in a foreign market. . . . Second, where the sale of an invention in a foreign market is material to the decision to commercialize the invention, 271(f) provides only negative incentives, effectively stifling technological growth and innovation... Third, the recent and dramatic change in the interpretation of the scope and function of 271(f) by the Federal Circuit in AT\&T, Eolas, and Union Carbide has introduced varying degrees of uncertainty into the high technology economic market, which is anathema to the entire patent regime."). 
balance the need to incentivize innovators by protecting method patents with the countervailing extraterritoriality concerns of the international community and infringement liability concerns of United States businesses. Upon thoughtful balancing of these concerns, it is recommended that Congress close the loophole created by Cardiac Pacemakers by enacting legislation that protects United States method patent owners from the newly created Cardiac Pacemakers loophole. 